\title{
Syngeneic Schwann Cells Derived from Adult Nerves Seeded in Semipermeable Guidance Channels Enhance Peripheral Nerve Regeneration
}

\author{
Véronique Guénard, ${ }^{1}$ Naomi Kleitman, ${ }^{2}$ Thomas K. Morrissey, ${ }^{2}$ Richard P. Bunge, ${ }^{2}$ and Patrick Aebischer ${ }^{1}$ \\ 'Section for Artificial Organs, Biomaterials and Cellular Technology, Brown University, Providence Rhode Island 02912 and \\ 2The Miami Project to Cure Paralysis, University of Miami School of Medicine, Miami, Florida 33136
}

At present, clinical strategies to repair injured peripheral nerve concentrate on efforts to attain primary suture of the cut nerve ends. If this is not possible, autografts are used to unite the separated nerve segments. Both strategies are based on the recognition that the Schwann cells resident in the peripheral nerve trunk play a crucial role in the regenerative process. Neither strategy may be feasible, however, in extensive or multiple injuries because the amount of autograft material is limited, and allografts are subject to immune rejection. Artificially produced nerve bridges constructed of autologous Schwann cells seeded in guidance channels could be used to overcome these limitations. In the present experiments, the potential of Schwann cells derived from adult nerves and seeded in permselective guidance channels to promote neurite regeneration across an 8 $\mathrm{mm}$ nerve gap was evaluated in transected rat sciatic nerves. Immunological sequalae were evaluated by comparing Schwann cells from syngeneic and heterologous rat strains. Schwann cells from either adult outbred (Sprague-Dawley, CD) rats or inbred (Fisher, F) rats were suspended in a Matrigel solution at a density of $80 \times 10^{6} \mathrm{cells} / \mathrm{ml}(C D)$ or 40 , 80 , or $120 \times 10^{6} \mathrm{cells} / \mathrm{ml}$ (F-40, F-80, and F-120 channels, respectively). Channels containing Schwann cells were compared to sciatic nerve autografts, empty channels, or channels filled with Matrigel alone. One day after seeding permselective synthetic guidance channels with a Schwann cell suspension, a central cable of Schwann cells oriented along the axis of the tube was formed due to syneresis of the hydrogel. By 3 weeks postimplantation, regenerating axons had grown into all channels and autografts. Sciatic nerve autografts supported extensive regeneration, containing 4$5 \times 10^{4}$ myelinated axons at the graft midpoint. The ability of channels containing syngenelc Schwann cells to foster regeneration was dependent on the Schwann cell seeding density. At the channel's midpoint, the myelinated axon population in F-120 tubes was intermediate between that in sciatic nerve autografts and F-80 channels, and was signifi-

Received Aug. 16, 1991; revised Jan. 31, 1992; accepted Mar. 30, 1992.

This work was supported by NIH Grant NS-26159 and Gliatech Inc. (P.A.) and NIH Grant NS-09923 (R.P.B.). We acknowledge the excellent technical support of Jules Jacob, Paula J. Weston, and Peggy Bates. We are grateful to Dr. J. Klose for his help with the statistical analysis and Robert Camarena for his assistance with photography.

Correspondence should be addressed to Dr. Patrick Aebischer, Division of Biology and Medicine, Box G-B393, Brown University, Providence, RI 02912.

Copyright (C) 1992 Society for Neuroscience 0270-6474/92/123310-11\$05.00/0 cantly higher than in F-40 or control channels. The nerve cable in Schwann cell-containing tubes consisted of larger, more organotypic fascicles than acellular control channels. In contrast, heterologous (CD) Schwann cells elicited a strong immune reaction that impeded nerve regeneration. The present study shows that cultured adult syngeneic Schwann cells seeded in permselective synthetic guidance channels support extensive peripheral nerve regeneration. Successful regeneration depends upon immune compatibility between donor and host, indicating the importance of developing large populations of autologous adult human Schwann cells if this approach is to find clinical use in the repair of peripheral nerve injury.

Current strategies to repair damaged peripheral nerve in humans are limited to end-to-end coaptation and nerve grafting. Nerve autografts are used clinically to span long nerve gaps, but availability of nerve for grafting is limited, and often multiple lengths of nerve graft are needed to approximate the volume between the injured nerve stumps (Ansselin and Davey, 1988; Kline and Hudson, 1990). Nerve allografts are a possible alternative, but immune rejection problems then necessitate immunosuppressant drug therapy (Pollard et al., 1973; Kline and Hudson, 1990). Experimental studies have demonstrated the importance of Schwann cells in peripheral nerve grafts in mediating regeneration (Hall, 1986a; Fawcett and Keynes, 1990). For instance, regrowing axons do not elongate through acellular nerve grafts if Schwann cell migration is impeded (Hall, 1986b). Schwann cells also have been shown to be effective in inducing regeneration from CNS tissues (Kromer and Cornbrooks, 1985, 1987; Smith and Stevenson, 1988). These findings suggest that, if available, transplanted Schwann cells may be useful as a substitute for autografts to repair injured nerves in both the PNS and CNS.

Synthetic guidance channels have been successfully used to bridge nerve gaps between the stumps of transected peripheral nerves (Lundborg et al., 1982; Williams et al., 1983; Madison et al., 1987; Aebischer et al., 1988, 1990). Schwann cells appear to mediate this regeneration. Schwann cells migrate into the channels along with perineurial-like cells along a preformed fibrin matrix (Williams et al., 1983). Humoral factors affecting Schwann cell adhesion and proliferation in vitro accumulate in the channels (Le Beau et al., 1988) and potentially control their migration. Following Schwann cell migration, regenerating axons elongate in the channels (Williams et al., 1983), most likely under the influence of molecules expressed by Schwann cells 
(see Fawcett and Keynes, 1990, for a review). By seeding guidance channels with Schwann cells prior to implantation, initial regenerative events may be bypassed and regeneration accelerated. This technique could be of clinical use if Schwann cells could be isolated from a patient's peripheral nerve, expanded in vitro, and then implanted at the site of the nerve injury. Providing a preformed Schwann cell cable should increase the gap distance that could be bridged between the two stumps of transected peripheral nerves and decrease the reconnection time with target tissue, thus improving functional recovery.

Recently, Morrissey et al. (1991) described a new technique for isolating Schwann cells from adult rat and human peripheral nerve. In the present study, Schwann cells from sciatic nerves of both adult inbred and outbred rats were isolated using this technique. The cells were suspended in Matrigel and seeded in permselective guidance channels. Their ability to enhance peripheral nerve regeneration was evaluated in a transected rat sciatic nerve model. We report here that guidance channels containing syngeneic Schwann cell support extensive regeneration, in some cases rivaling that seen in sciatic nerve autografts. Successful regeneration depends, however, upon high Schwann cell density and immune compatibility between donor and host.

\section{Materials and Methods}

\section{Schwann cell cultures}

Schwann cells from adult rat sciatic nerves were isolated according to a technique modified from that of Morrissey et al. (1991) in which Schwann cells were harvested from peripheral nerves following a period of "in vilro Wallerian degeneration." Adult male inbred Fisher 344 rats (Taconic, Germantown, NY) weighing 250-300 gm and adult male outbred CD rats (Charles River Laboratories, MA) weighing 400-450 gm were used. Sciatic nerves were collected into Dulbecco's Modified Eagle's Medium (DMEM; GIBCO Laboratories, Long Island, NY), stripped of their epineurium, and chopped into $1 \mathrm{~mm}^{2}$ pieces. The nerve pieces were placed on Vitrogen-coated (Collagen Corporation, Palo Alto, CA) Petri dishes in DMEM supplemented with $10 \%$ fetal calf serum (FCS; GIBCO) and penicillin/streptomycin (1000 U/ml; DMEM-FCS). Every $5 \mathrm{~d}$, the nerve pieces were transferred into new Petri dishes, leaving behind fibroblasts that had migrated out onto the Vitrogen. Most fibroblasts had left the nerve explants after three or four transfers. The cells remaining in the explants were then dissociated by incubating the nerve chunks at $37^{\circ} \mathrm{C}$ for $2 \mathrm{hr}$ in $\mathrm{Ca}^{2+} / \mathrm{Mg}^{2+}$-free Hanks' Balanced Salt Solution (HBSS) containing 0.3\% trypsin (Sigma, St. Louis, MO), 0.1\% collagenase (Sigma), and 0.1\% hyaluronidase (Sigma). The cells were then triturated, washed, and cultured in DMEM-FCS. The following day, the culture medium was replaced with mitogenic medium containing DMEM, FCS, forskolin ( $2 \mu \mathrm{M}$; Sigma), and pituitary extract (10 $\mu \mathrm{g} / \mathrm{ml}$; Collaborative Research Inc., Bedford, MA) (Porter et al., 1986). For the next 4-6 d, Schwann cells were cultured in mitogenic medium at $37^{\circ} \mathrm{C}$ in a humidified atmosphere with $5 \% \mathrm{CO}_{2}$.

\section{Evaluation of the Schwann cell cultures}

The purity of the Schwann cell cultures was quantified on the day of implantation. At the same time the channels were filled with Schwann cells (see below), some cells were seeded on uncoated glass coverslips placed in a six-well plastic plate at a density of $10^{s}$ cells/well in DMEMFCS. The purity of the cultures was determined by immunostaining using both Schwann cell and fibroblast markers. Schwann cells were labeled with both mouse monoclonal $217 \mathrm{c}$ antibody, a selective marker for NGF receptors (NGFr; Kumar et al., 1990), and polyclonal S-100 antibody (Dakopatts, Santa Barbara, CA). The $217 \mathrm{c}$ antibody was generously provided by Dr. J. de Vellis (University of California at Los Angeles). Contamination with fibroblasts was assessed using a rabbit polyclonal fibronectin antibody, generously supplied by $\mathrm{Dr}$. R. Morris (National Institute for Medical Research, London, England).

For Schwann cell labeling, cells were fixed using a 3\% solution of paraformaldehyde in $0.01 \mathrm{M}$ PBS at $\mathrm{pH} 7.4$ and incubated at room temperature with either the $217 \mathrm{c}(1: 100)$ or $S-100(1: 200)$ antibody with $0.2 \%$ Triton $\mathrm{X}-100$ in buffer. Cells were then incubated with secondary rabbit anti-mouse antiserum (1:50; Sternberger-Meyer, Jarrettsville, MD) or goat anti-rabbit antiserum (1:100; Sternberger-Meyer) followed by mouse (1:50; Sternberger-Meyer) or rabbit (1:100) peroxidase-antiperoxidase (PAP; Dakopatts), respectively. For fibroblast identification, cells were fixed with a $95 \%$ ethanol, $5 \%$ glacial acetic acid (v/v) solution at $-20^{\circ} \mathrm{C}$ for $20 \mathrm{~min}$ and incubated overnight at $4{ }^{\circ} \mathrm{C}$ with rabbit antifibronectin antiserum $(1: 20,000)$ in buffer with $0.2 \%$ Triton X-100. Secondary goat anti-rabbit antiserum (1:200) and rabbit PAP (1:100) were then used. All reactions were visualized with a solution of $0.05 \%$ diaminobenzidine tetrahydrochloride (Sigma) and $0.01 \%$ hydrogen peroxide (Sigma). The cells were then counterstained with cresyl violet. The percentage of $217 \mathrm{c}$-positive, S-100-positive, and fibronectin-positive cells was evaluated at a magnification of $160 \times$ on 25 randomly selected fields.

\section{Guidance channel preparation}

Guidance channels consisted of a 60:40 acrylonitrile vinylchloride (PAN/ PVC) copolymer tubing with a $1.12 \mathrm{~mm}$ inner diameter and a 0.126 $\mu \mathrm{m}$-thick wall. These tubes were fabricated using a dry-jet wet spinning technique (Cabasso, 1980; $\Lambda$ ebischer et al., 1991). The tubes featured a smooth inner skin connected to a partially fenestrated outer skin by a trabecular network. The inner skin provided a permselective barrier, with a molecular weight cutoff of 50,000 Da. Prior to seeding, the tubing was cleaned and sterilized as previously described (Aebischer et al., 1988).

Seeding with Schwann cells. Schwann cells were removed from dishes by treatment with $0.05 \%$ trypsin and $0.02 \%$ EDTA (Sigma) for $5 \mathrm{~min}$ at $37^{\circ} \mathrm{C}$ and collected by centrifugation. The cells were pelleted and washed in DMEM, and the number of live cells was evaluated with trypan blue exclusion using a hemocytometer. Schwann cells were then gently suspended in a 70:30 (v/v) solution of DMEM : Matrigel (Collaborative Research Inc.). Syngeneic Schwann cells were suspended at a final density of either $40 \times 10^{6}$ cells $/ \mathrm{ml}$ (F-40 channel), $80 \times 10^{6}$ cells/ $\mathrm{ml}\left(\mathrm{F}-80\right.$ channel), or $120 \times 10^{6} \mathrm{cells} / \mathrm{ml}$ (F-120 channel). Heterologous (CD) Schwann cells were suspended at a final concentration of $80 \times$ $10^{6}$ cells $/ \mathrm{ml}$ (CD-80 channel). Permselective tubes were filled with the Schwann cell suspensions by attaching $10-\mathrm{cm}$-long tubes to a syringe and drawing the Schwann cell solution up into the tubes. Care was taken to avoid introducing air bubbles into the tubes. The filled tubes were then placed in DMEM at room temperature to allow for gellation of the cell suspension and cut into 10-mm-long pieces. These tubes were closed at each end using PAN/PVC copolymer glue. The seeded channels were kept in DMEM for $24 \mathrm{hr}$ at $37^{\circ} \mathrm{C}$. Each F-40, F-80 (and CD-80), and F-120 channel contained approximately $0.32,0.64$, and $1.28 \times 10^{6}$ Schwann cells, respectively. Control channels were filled with a $70: 30$ solution of DMEM : Matrigel in a similar way (F-CD- $\Phi$ channel) or left empty. The closing caps were removed at the time of implantation.

\section{Arrangement and characterization of the cells in the channels}

Prior to implantation, tubes were collected (1) immediately after filling, (2) on the day of surgery, and (3) $5 \mathrm{~d}$ postseeding, and fixed overnight in $2.5 \%$ paraformaldehyde in $0.1 \mathrm{M}$ PBS at $\mathrm{pH} 7.4$. The channel's content was observed using either scanning electron microscopy (SEM) or light microscopy. For SEM, the channels were postfixed, dehydrated in dimethylaminomethyl phenol, critical point dried, and observed using a Hitachi 2700 microscope. For light microscopy, the samples were dehydrated, infiltrated overnight in Historesin (Cambridge Instruments, Deerfield, IL), and embedded. Five-micrometer-thick longitudinal sections of the seeded tubes were cut using a Reichert-Jung 2050 microtome (Cambridge Instruments). Sections were counterstained with cresyl violet.

To aid in characterizing the cells seeded in the tubes, channels collected on the day of implantation were fixed overnight in 3\% paraformaldehyde in $0.1 \mathrm{M}$ PBS at $\mathrm{pH} 7.4$. The specimens were frozen on dry ice, and $20-\mu \mathrm{m}$-thick longitudinal sections were obtained using a Reichert-Jung 1800 cryocut (Cambridge Instruments). The sections were mounted on aminopropyltriethoxysilane-coated glass slides and reacted with the $217 \mathrm{c}$ antibody as described above.

\section{Guidance channel implantation}

Inbred Fisher 344 rats weighing 100-125 gm were anesthetized with pentobarbital (Nembutal) and their left sciatic nerve exposed as previously described (Guénard et al., 1991). The nerve was sectioned 3 $\mathrm{mm}$ proximal to the tibioperoneal bifurcation, and a 4-5-mm-long piece 

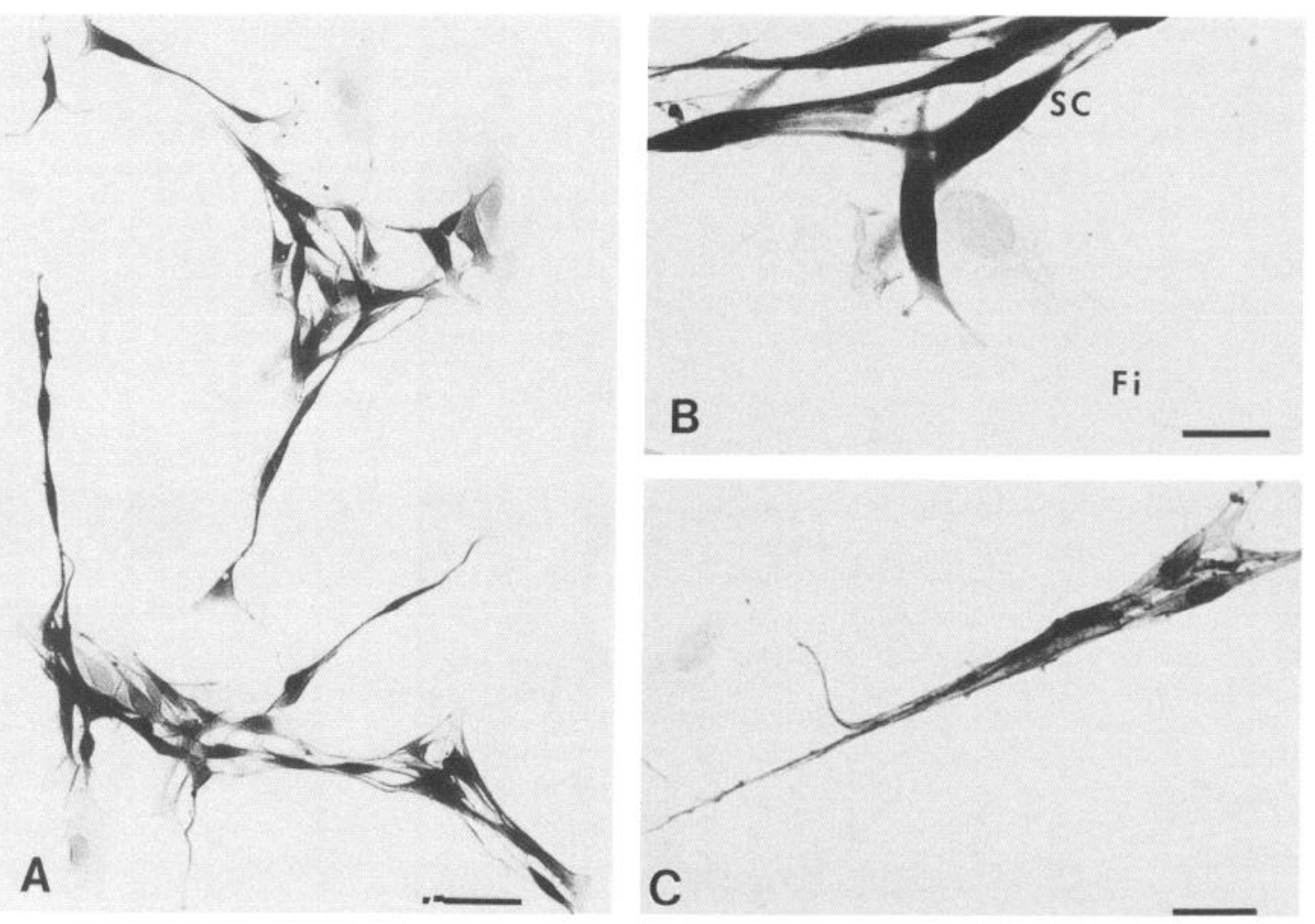

Figure 1. Light micrographs of Schwann cell cultures stained with S-100 $(A, B)$ and $217 \mathrm{c}(C)$ antisera. $A$, S-100-positive cells formed interconnected networks, aligning side by side and end to end. $B$ and $C$, Both spindle- and triangular-shaped Schwann cells are darkly stained (SC). Unlabeled cells with large ovoid nuclei $(\mathrm{Fi})$ are seen among the Schwann cells; these fibronectin-positive cells are fibroblasts (data not shown). Scale bars: $A$, $100 \mu \mathrm{m} ; B$ and $C, 20 \mu \mathrm{m}$.

of nerve was resected and discarded. Both the proximal and distal nerve stumps were secured $1 \mathrm{~mm}$ within the channels, leaving an 8 -mm-long nerve gap. The wound was then closed. Rats were implanted for 3 weeks with empty $(n=6)$, F-CD- $\Phi(n=6)$, F-40 $(n=7)$, F-80 $(n=7)$, F-120 $(n=6)$, and CD-80 $(n=6)$ channels. Animals were housed in plastic cages in rooms with $12 \mathrm{hr}$ on-off light cycles and received food and water ad libitum.

\section{Sciatic nerve autografting}

The left sciatic nerve was exposed and cut both 3 and $11 \mathrm{~mm}$ proximal to the tibioperoneal bifurcation. The 8-mm-long piece of sciatic nerve was removed and rotated to align the distal end of the nerve segment with the proximal nerve stump and the proximal end of the nerve piece with the distal nerve stump. The nerve autograft was secured in place using four to six 10.0 nylon suture epineurial stitches. Six rats received sciatic nerve autografts for 3 weeks.

\section{Implant retrieval and evaluation}

Rats were deeply anesthetized with pentobarbital (Nembutal) and transcardially perfused with buffered fixative, and both the channels and autografts were excised (Guénard et al., 1991). Samples were fixed overnight in $3 \%$ paraformaldehyde and $2.5 \%$ glutaraldehyde in $0.1 \mathrm{~m}$ PBS at pH 7.4, transversely cut at their midpoint, postfixed, dehydrated in graded ethanol, infiltrated, and embedded in Spurr resin. Specimens were sectioned $2,4,6$, and $8 \mathrm{~mm}$ distal from the proximal suture (sections S2, S4, S6, and S8, respectively) using a Sorvall MT-5000 microtome. Semithin sections were stained with toluidine blue and ultrathin sections with Reynold's lead citrate and uranyl acetate for transmission electron microscopy. The cable cross-sectional surface area (CSA) of the regenerated tissue, number of myelinated axons, and number of blood vessels per $\mathrm{mm}^{2}$ of CSA were quantified at each sample point using a computerized morphometric analysis system (CUE-2, Olympus Corp., Lake Success, NY) interfaced with a Zeiss IM35 microscope. The number of myelinated axons in four animals that had received either empty, F-CD- $\Phi, \mathrm{F}-40, \mathrm{~F}-80$, or F-120 channels was also counted at the proximal nerve stump level (S0 section). To investigate whether the transplanted syngeneic Schwann cells could have induced branching inside the channels, the ratio of myelinated axon populations at level S2 versus level S0 was calculated and compared. Ultrathin sections were examined at sections S4 and S8 for the presence of Schwann cells, unmyelinated axonal profiles, reactive cells, and blood cells using a Philips 410 electron microscope.

\section{Statistical analysis}

All data are presented as means \pm SEM. The data were subjected to a two-way analysis of variance (MANOVA) followed by Tukey tests for multiple comparisons between pairs of means, using a commercially available statistical software (spss, release 4.1). The Tukey test was performed when the two-way analysis of the variance indicated overall statistical significance. Statistical significance was accepted for $p<0.05$.

\section{Results}

\section{Evaluation of the Schwann cell cultures}

For each immunostain, an average of 1000 cells was counted. Dissociation of nerve explants from both Fisher and CD rats yielded cell populations that were $97 \% 217 \mathrm{c}$ and S-100 positive $(97.2 \pm 0.6 \%, 97.0 \pm 1.0 \%$, respectively). These cells exhibited two distinct morphologies (Fig. 1). Most of the cells were small, elongated, and spindle shaped. In the culture dishes, these Schwann cells had a tendency to line up side by side or end to end and formed interconnected networks (Fig. 1A). Following expansion in mitogenic medium, some slightly larger $217 \mathrm{c} / \mathrm{S}$ 100 -positive cells, tripolar in shape with a fibroblast-like appearance, were also observed. These Schwann cells may have lost their characteristic spindle shape due to the presence of forskolin in the culture medium (Porter et al., 1986). A few 

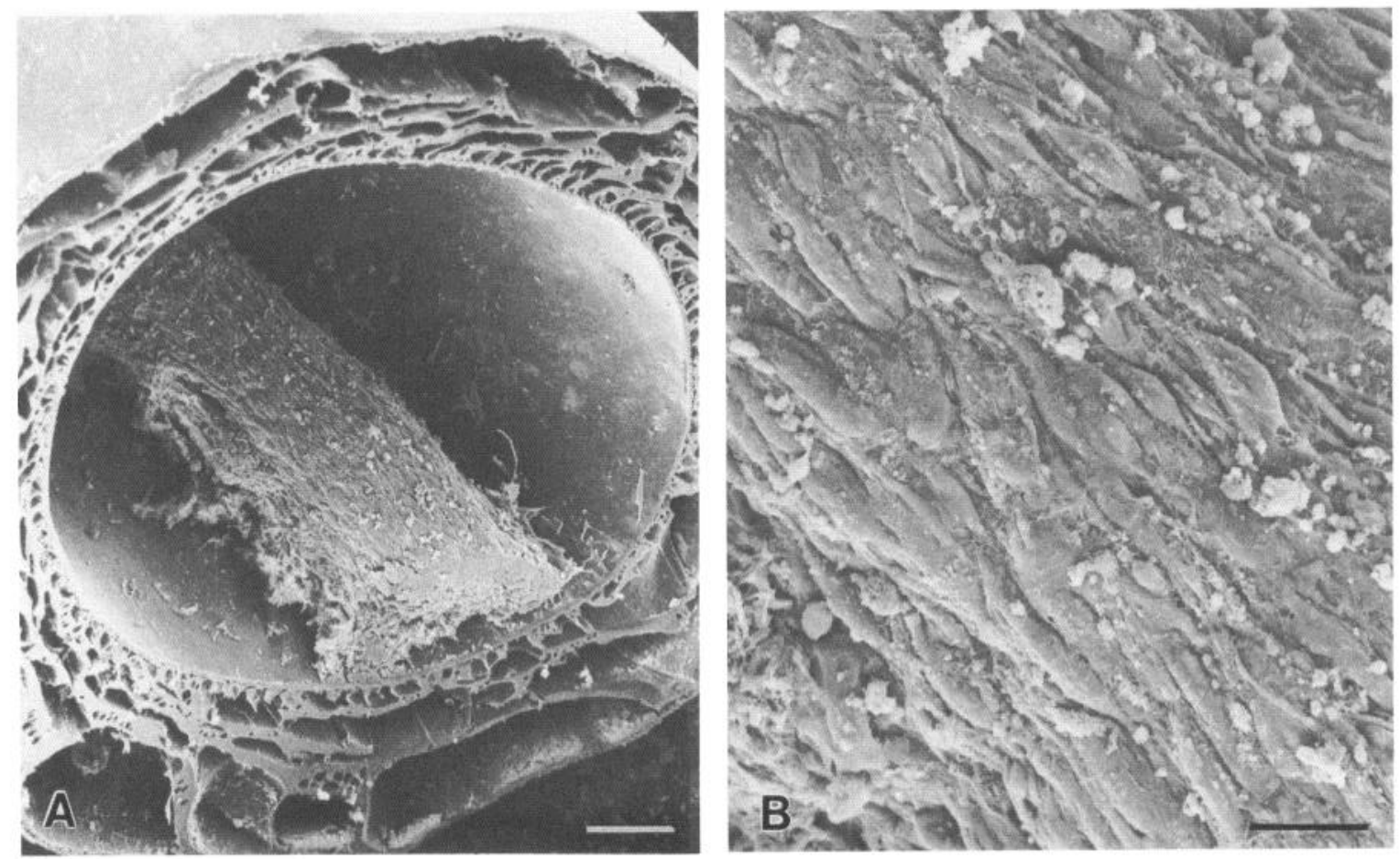

Figure 2. Scanning electron micrographs showing the arrangement of a Schwann cell suspension in Matrigel $1 \mathrm{~d}$ after seeding a permselective PAN/PVC tube in vitro. $A$, Note the formation of a longitudinally oriented Schwann cell cable. $B$, At higher magnification, notice the Schwann cell orientation along the main axis of the tubes. Scale bars: $A, 100 \mu \mathrm{m} ; B, 20 \mu \mathrm{m}$.

$217 \mathrm{c} / \mathrm{S}-100$-negative cells with large cresyl violet-stained ovoid nuclei were scattered among Schwann cells (Fig. $1 B, C$ ); these cells were fibronectin positive and therefore are likely to be fibroblasts (data not shown). Fibronectin-positive cells represented $3 \%$ of the cell population $(3.0 \pm 1.0 \%)$. Cell viability as determined by trypan blue exclusion was above $95 \%$ at the time the channels were seeded.

\section{Arrangement of the Schwann cells in the channels}

One day after seeding the tubes, a Schwann cell cable free of attachment from the channel's wall was observed with both SEM (Fig. 2A) and light microscopy. In tubes containing Schwann cells, the cells were aligned along the longitudinal axis of the tubes, arranging themselves side by side and end to end (Fig. $2 B$ ). A similar pattern was observed after $5 \mathrm{~d}$ in culture (data not shown). The aligned cells were $217 \mathrm{c}$ positive, indicating that seeded Schwann cells expressed NGFr at the time of implantation.

\section{Sciatic nerve autografts}

Autografts of sciatic nerves were used as a standard against which to compare regeneration through guidance channels. Upon retrieval, no sign of graft rejection was observed. The cable CSA of the autografts decreased up to section S4 and then increased toward the distal nerve stump (Fig. $3 A$ ). At any point along their length, autografts were significantly larger than any cable regenerated through channels. Autografts consisted of two nerve bundles with numerous nerve microfascicles surrounded by a thin epineurial-like layer. Each bundle contained blood vessels and numerous nerve microfascicles with unmyelinated and myelinated axons with their associated Schwann cells (Fig. 4D); degenerating figures were often seen. The number of myelinated axons decreased from S2 to S4, but increased to S6 and again declined to its lowest value at $\mathbf{S 8}$. Overall, there was a decrease in the mean number of myelinated axons along the autografts (Fig. $3 B$ ). The number of blood vessels per $\mathrm{mm}^{2}$ of CSA in the nerve autograft was smaller as compared to the nerve regenerated through any type of channel (Fig. 5); however, the difference was not statistically significant.

\section{Schwann cell-seeded channels}

Upon retrieval, the outer surface of all the channels showed a minimal tissue reaction, consisting of a layer of macrophagelike cells and a few layers of fibroblast-like cells. A cable bridging both nerve stumps regenerated in all the tubes, whether they were empty, filled with Matrigel, or filled with either outbred or inbred Schwann cells suspended in Matrigel. At any point along the tubes, the regenerated nerve cables were round in shape, and separated from the inner wall of the channels by an acellular gel. The morphology of the regenerated nerve cables differed depending upon whether syngeneic or heterologous Schwann cells were implanted.

\section{Syngeneic Schwann cells}

Cable cross-sectional surface area. The cable CSA was lower in the middle (sections S4 and S6) of the tubes than at either end and maximal at the distal end (S8), regardless of the channel type (Fig. $3 A$ ). An overall significant difference between groups was seen by MANOVA when autografts (which were significantly larger than all other groups along the length of the graft) were included $(p<0.05)$. However, comparisons of pairs of means of channel groups revealed no significant differences.

Morphology. In all groups of channels seeded with syngeneic Schwann cells, cables contained nerve microfascicles and blood 
A

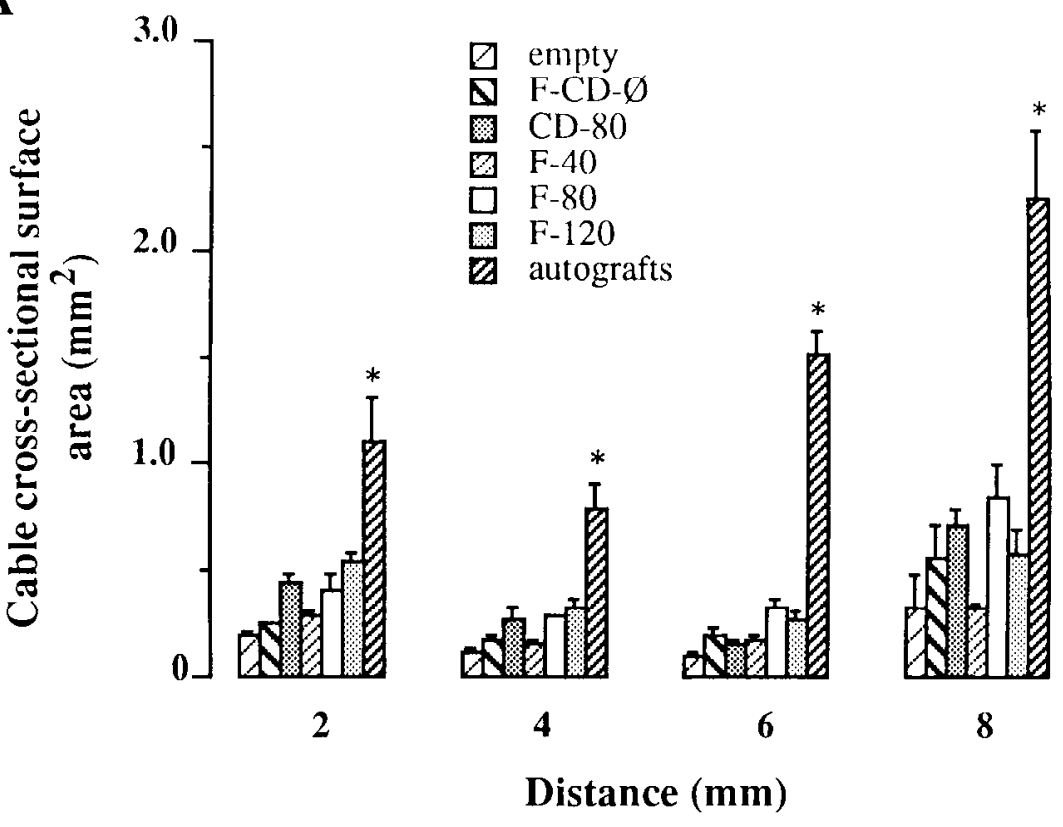

B

Figure 3. Cable CSA $(A)$ and number of myelinated axons $(B)$ of transverse sections taken $2,4,6$, and $8 \mathrm{~mm}$ from the proximal suture in empty, F-CD- $\Phi$, F-40, F-80, F-120, and CD-80 channels and in sciatic nerve autografts 3 weeks postimplantation. Data represent means \pm SEM. Two-way MANOVA followed by Tukey tests was used to test statistical significance between pairs of means. *, statistical significance $(p<$ 0.05 ) between either sciatic nerve autografts, F-40, F-80, or F-120 channels as compared to F-CD- $\Phi$ and empty channels; ${ }^{* *}$, statistical significance $(p$ $<0.05$ ) between sciatic nerve autografts and F-120 channels.

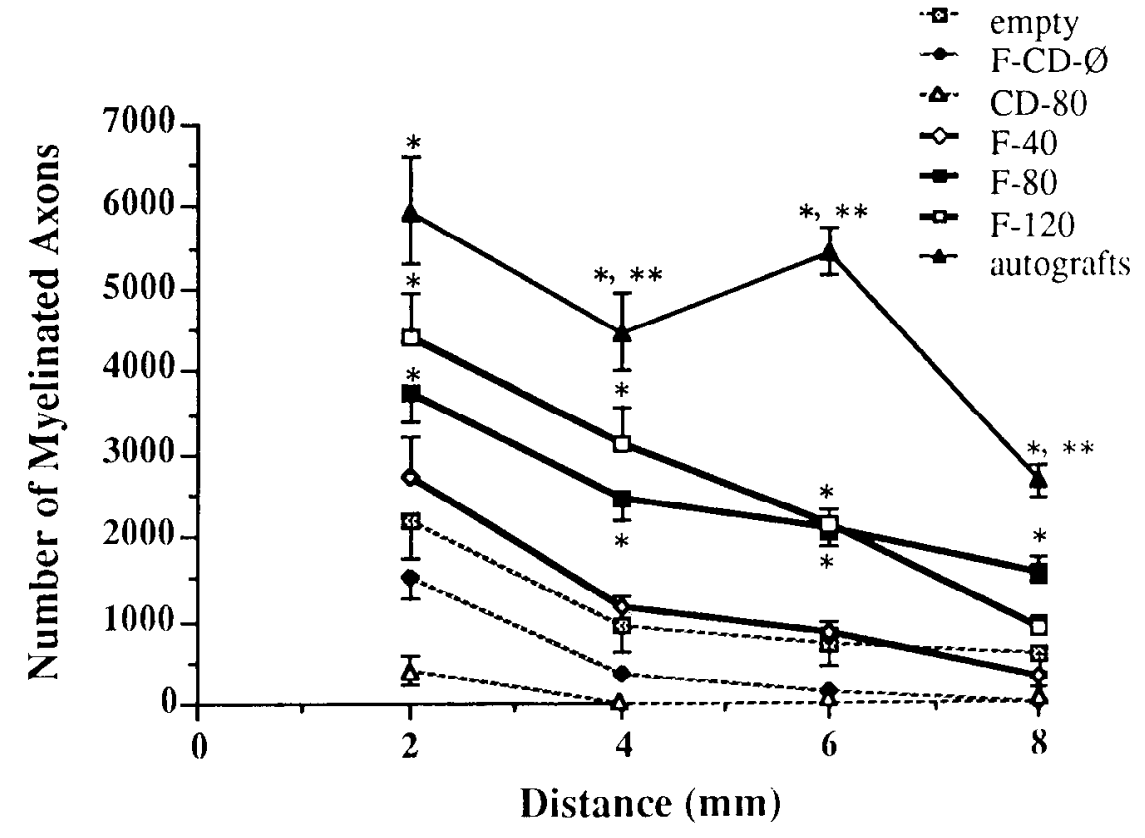

vessels surrounded by a thin epineurial-like layer (Fig. $6 A, D, G$ ). The thickness of the epineurial-like layer as a percentage of the CSA was similar in all types of channels (data not shown). At sections along empty, F-40, F-80, and F-120 channels, microfascicles contained both unmyelinated and myelinated axons associated with Schwann cells (Figs. $4 C ; 6 B, C, H, I ; 7 A, B$ ). In contrast, in F-CD- $\Phi$ channels, unmyelinated axons bridged the nerve gap but myelinated axons only elongated up to section $\mathrm{S} 6$ in two cases, and $\mathrm{S} 4$ in the remaining four cases (Fig. $6 E, F$ ). In addition, regenerated tissue in F-40, F-80, and F-120 channels showed less microfasciculation as compared to tissue regenerated in both empty and F-CD- $\Phi$ tubes (Fig. 6, B,C,E,F vs. $H, I)$. In empty and F-CD- $\Phi$ channels, the microfascicles were well separated by numerous fibroblast-like cells and collagen fibrils. Occasionally, small patches of Matrigel containing cells not in contact with axons were seen in the center of the cables regenerated in Schwann cell-seeded channels whereas acellular patches of Matrigel were seen in the center of cables regenerated in F-CD- $\Phi$ channels.

Myelinated axons. Overall, the number of myelinated axons significantly decreased along the length of all the channels $(p<$ 0.05 ) (Fig. 3B). Cables regenerated in F-80 and F-120 channels contained significantly more myelinated axons as compared to empty and F-CD- $\Phi$ channels, except at S8 where the difference between F-120 channels and F-CD- $\Phi$ channels was not significant (Fig. $3 B$ ). The mean number of myelinated axons in cables 

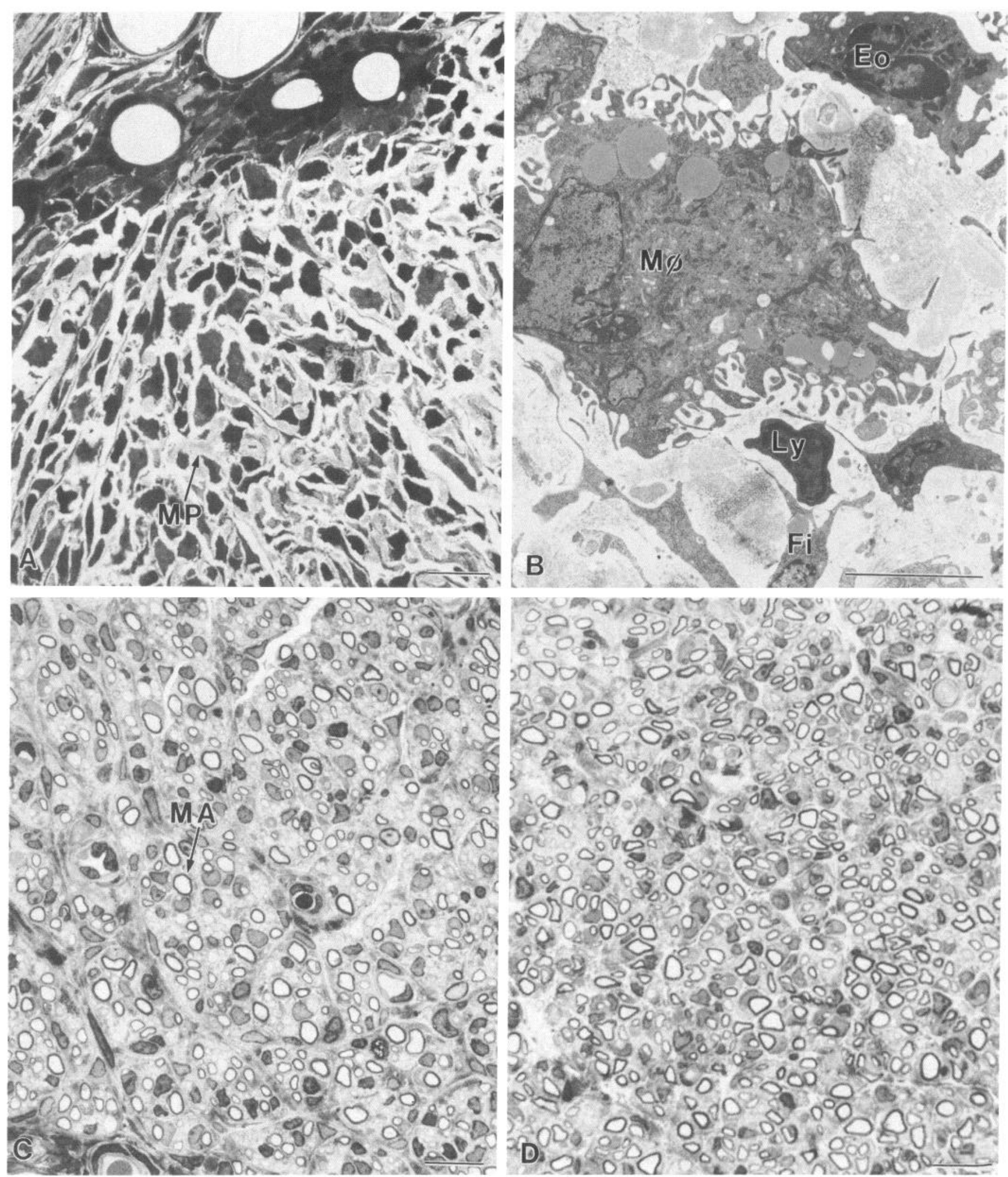

Figure 4. Light micrographs of toluidine blue-stained transverse sections taken $4 \mathrm{~mm}$ distally to the proximal suture in CD-80 $(A)$, F-80 channels $(C)$, and sciatic nerve autografts $(D), B$, transmission electron micrograph taken in a CD-80 channel 3 weeks postimplantation. In $A$, numerous reactive cells are seen among Matrigel patches $(M P)$. At higher magnification $(B)$, macrophage-like cells $(M \phi)$, eosinophils $(E o)$, lymphocytes $(L y)$, and fibroblasts $(F i)$ can be identified. Note the absence of axons. $C$ and $D$, Myelinated axons $(M A)$ with associated Schwann cells are seen. Scale bars: $A, C$ and $D, 10 \mu \mathrm{m} ; B, 5 \mu \mathrm{m}$ 
Figure 5. Number of blood vessels per square millimeter of cable CSA in transverse sections taken $2,4,6$, and 8 $\mathrm{mm}$ from the proximal suture in empty, F-CD- $\Phi$, F-40, F-80, F-120, and CD80 channels and in sciatic nerve autografts 3 weeks postimplantation. Data represent means \pm SEM. Two-way MANOVA followed by Tukey tests was used to test statistical significance between pairs of means. ${ }^{*}$, statistical significance $(p<0.05)$ between F-CD- $\Phi$ channels and either F-40, F-80, F-120, CD-80, or empty channels and sciatic nerve autografts.

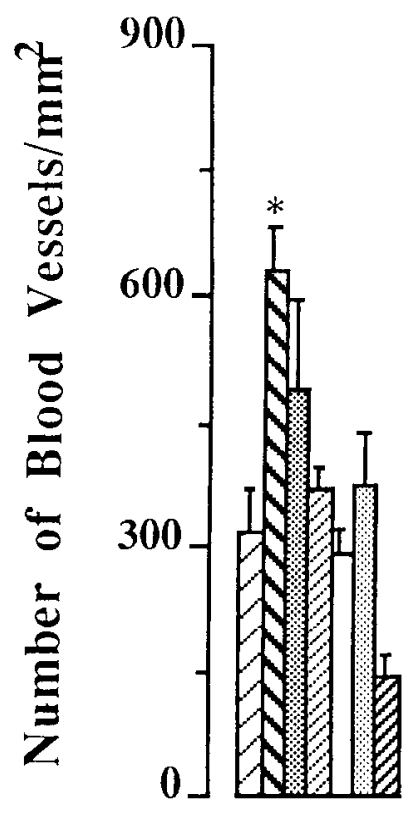

2

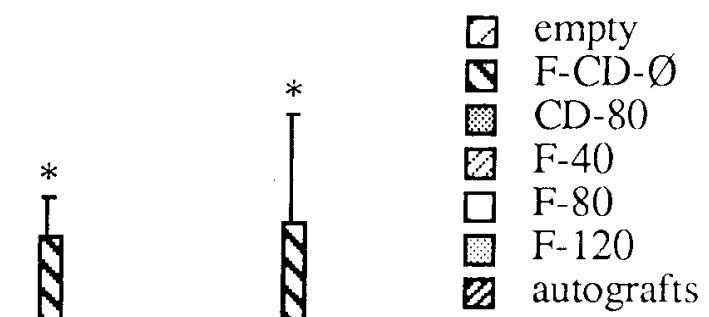

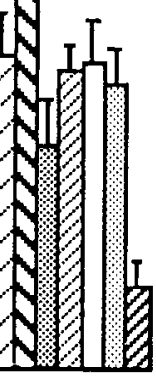

4

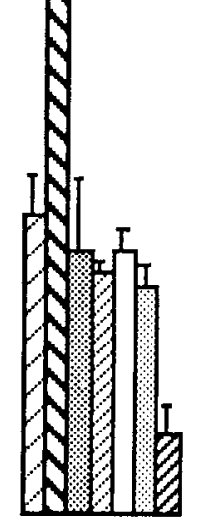

6

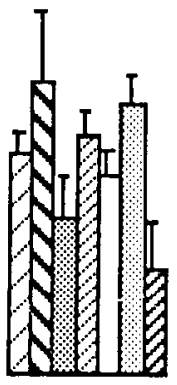

8

\section{Distance (mm)}

regenerated in channels seeded with Schwann cells at a low density (F-40 channels) was close to that in cables extending through control channels. At S2, values in F-40 channels were slightly higher than in both empty and F-CD- $\Phi$ channels, whereas at $\mathrm{S} 4, \mathrm{~S} 6$, and $\mathrm{S} 8$ values in F-40 channels were similar to those in empty channels but larger than those in F-CD- $\Phi$ channels (Fig. 3B). The mean number of myelinated axons extending through the channels increased in relation to the Schwann cellseeding density in the proximal portion of the channels, as far as $\mathrm{S6}$ (Fig. $3 B$ ). The mean number of myelinated axons in F-80 and F-120 channels was significantly larger than in F-40 channels $(p<0.05)$, except at S8 where the difference between F- 120 and F-40 channels was not statistically significant. The highest seeding density (F-120 channels) yielded the best regeneration. While F-120 values were smaller than in the autografts at all sections (MANOVA), the difference between means of myelinated axons at the proximal end of the channels (S2) was not statistically significant $(p>0.05)$. Distally, at $\mathbf{S} 8$, the number of myelinated axons in F-120 declined to levels not different from controls (Fig. $3 B$ ). Cables extending in F-CD- $\Phi$ tubes also contained fewer myelinated axons than cables regenerated in empty tubes (Fig. 3B); however, the difference was not statistically significant.

The ratio of the numbers of myelinated axons at sections S2 versus sections $\mathrm{S} 0$ was determined to assess axonal branching at the entrance of the channels. Mean ratio values increased in seeded channels as compared to control channels $(0.43 \pm 0.03$, $0.66 \pm 0.13$, and $0.62 \pm 0.04$ in F-40, F-80, and F-120 channels vs. $0.28 \pm 0.08$ and $0.39 \pm 0.07$ in empty and F-CD- $\Phi$ channels, respectively). An overall significant difference between groups was seen by MANOVA $(p<0.05$ ). Tukey tests (to compare mean ratio values) indicated that the increase was statistically significant between F-80, F-120, and both empty and F-CD- $\Phi$ channels $(p<0.05)$.

Blood vessels. The number of blood vessels per $\mathrm{mm}^{2}$ of CSA did not vary significantly between empty, F-40, F-80, and F- 120 channels (Fig. 5). At any section along the tubes except S8, however, cables regenerated in F-CD- $\Phi$ channels contained significantly more blood vessels than empty, F-40, F-80, and F-120 channels (Fig. 5). The number of blood vessels per square millimeter of CSA in F-40, F-80, and F-120 channels was greater than in the nerve autografts; the difference was stastically significant at S4.

\section{Heterologous Schwann cells}

The cable CSA of the regenerated CD- 80 cablcs decreased from the proximal nerve stump to section $\mathrm{S6}$, and then increased at section S8 (Fig. $3 A$ ), similarly to other channels. In contrast to syngeneic Schwann cells, heterologous Schwann cells elicited a strong immune reaction. Numerous reactive cells, including macrophage-like cells, eosinophils, and lymphocytes, were seen infiltrating the tissue (Fig. $4 A, B$ ), especially from the distal end of the channels. Only at level S2 did the regenerated tissue resemble other cables, consisting of blood vessels and nerve microfascicles surrounded by an epineurial-like sheath. Myelinated axons extended through section $\mathrm{S} 2$ in all CD-80 tubes but were never seen at level S4 (Fig. 3B). Unmyelinated axons were only seen in one of the six CD-80 channels at S4. There was no significant difference in number of blood vessels per square millimeter of CSA in CD-80 channels as compared to the other type of channels, except F-CD- $\Phi$ channels (Fig. 5).

\section{Discussion}

The present study shows that cultured adult syngeneic Schwann cells expanded after their isolation from degenerated sciatic nerve segments and suspended in Matrigel are able to form an oriented central cable in synthetic guidance channels. Such Schwann cell cables enhanced peripheral nerve regeneration through permselective guidance channels in a seeding density-dependent fashion. Our findings show that myelinated axon populations in- 

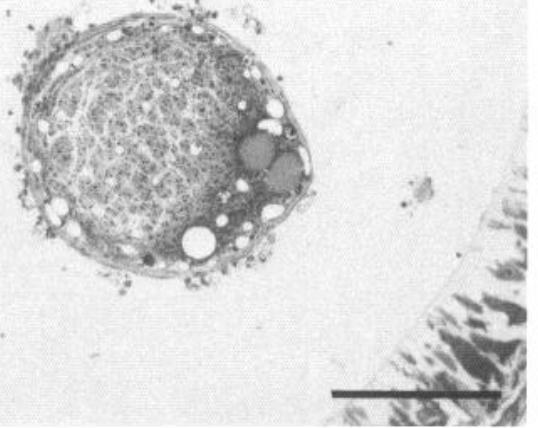

A
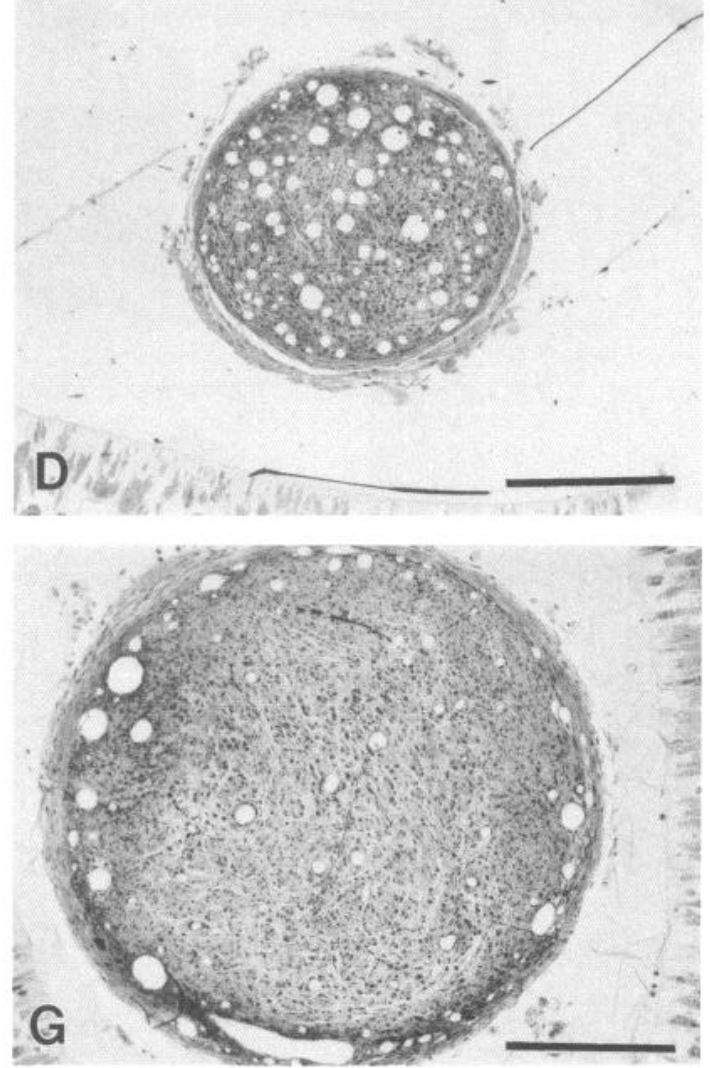
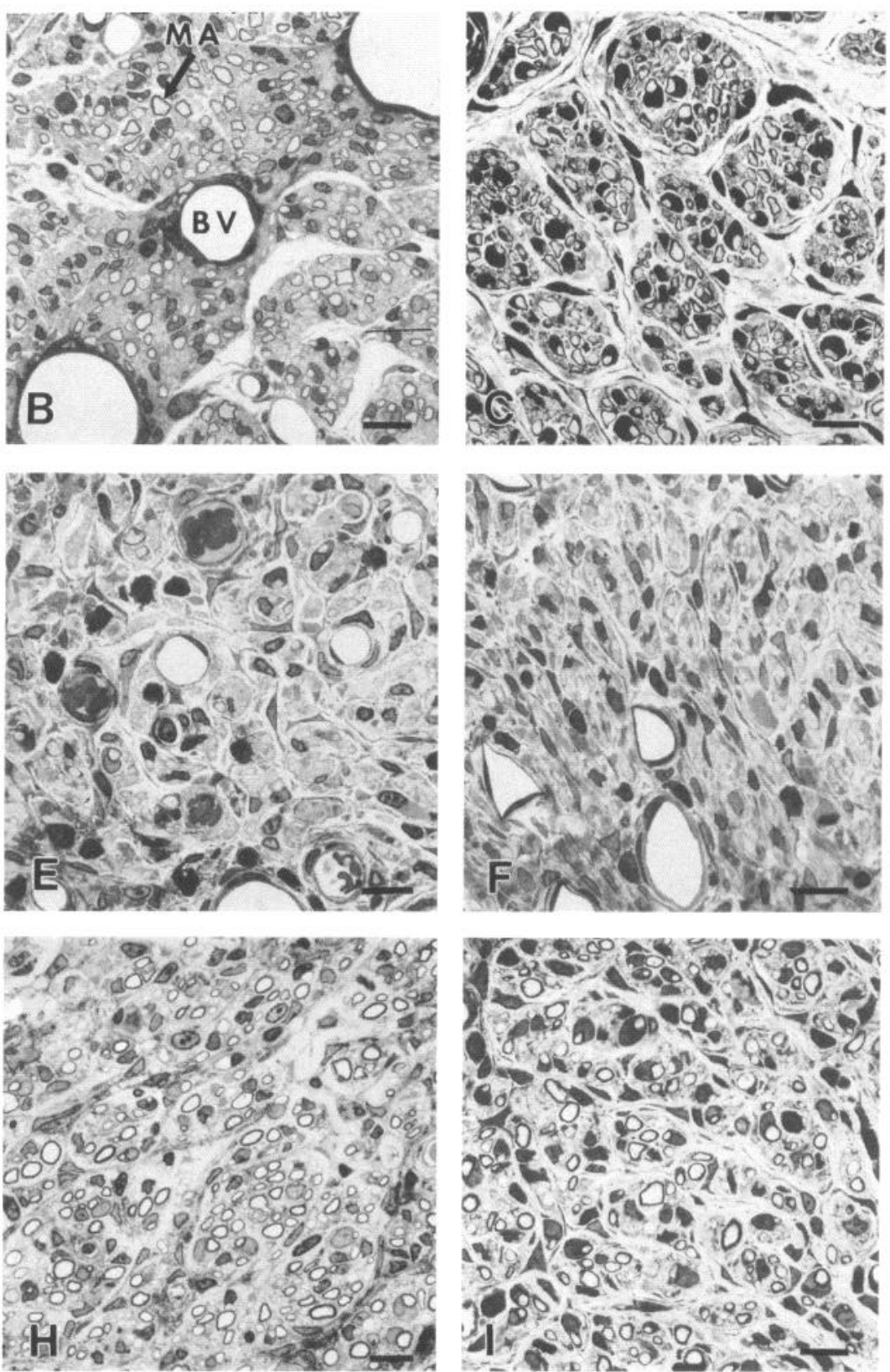

Figure 6. Light micrographs of toluidine blue-stained transverse sections taken $4 \mathrm{~mm}$ distally to the proximal suture in empty $(A)$, F-CD- $\Phi(D)$, and F-80 $(G)$ channels 3 weeks postimplantation. Note the increased cable cross-sectional surface area in the Schwann cell-containing channel. At higher magnification, light micrographs of transverse sections taken, respectively, 4 and $8 \mathrm{~mm}$ distally to the proximal suture in empty ( $B$, $C$ ), F-CD- $\Phi(E, F)$, and F-80 $(H, I)$ channels showing nerve microfascicles with blood vessels $(B V)$ and numerous myelinated axons $(M A)$. At the channels' midpoint, the myelinated axon density was lower in F-CD- $\Phi$ channels $(E)$ as compared to empty $(B)$ and F-80 channels $(H)$. At the distal nerve stump level, myelinated axons are observed in both empty $(C)$ and F-80 channels $(I)$, but not in F-CD- $\Phi$ channels $(F)$. Note the difference in microfasciculation between empty and F-80 channels. Scale bars: $A, D$, and $G, 200 \mu \mathrm{m} ; B, C, E, F, H$, and $I, 5 \mu \mathrm{m}$.

creased in channels containing syngeneic Schwann cells as compared to channels filled with Matrigel. Although the Matrigel solution itself induced a decrease in myelinated axon population relative to empty channels, as previously reported (Valentini et al., 1987), cultured adult Schwann cells were able to overcome the inhibitory effect of the Matrigel solution and enhance the regenerative processes, suggesting that the augmentation of regeneration seen was attributable to the presence of added Schwann cells. Shine et al. (1985) also reported successful regeneration through blind-ended polyethylene channels filled with PNS cultures containing Schwann cells, fibroblasts, and neurons from dorsal root ganglia (DRG). Interpretation of these results is complicated by the fact that DRG neurons are known to be mitogenic for Schwann cells and their growth may have stimulated the proliferation of endogenous Schwann cells. Because axons may be induced to grow by cofasciculation with other axons or by contact with Schwann cells, it is not possible from their data to differentiate the effects of the various implanted cell types on regeneration.

Although the mechanisms by which Schwann cells triggered nerve regeneration were not explored in this study, their ability to express molecules with neurotrophic activities and/or me- 

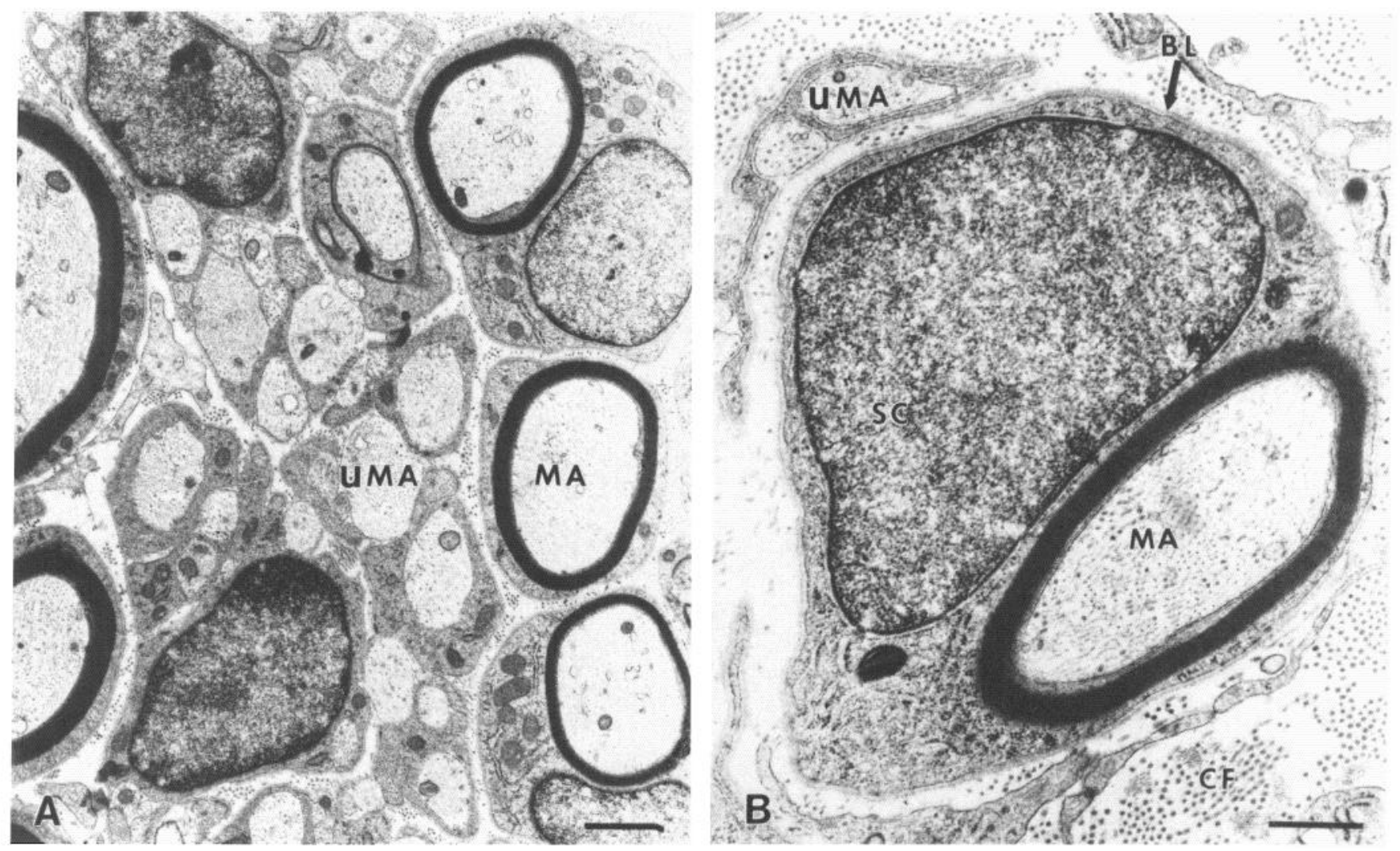

Figure 7. Transmission electron micrographs taken at the midpoint of a cable regenerated in a F-80 channel 3 weeks postimplantation. $A$, Both unmyelinated $(U M A)$ and myelinated $(M A)$ axons are associated with Schwann cells. At higher magnification $(B)$, myelinated $(M A)$ and unmyelinated $(U M A)$ axons are seen with Schwann cells $(S C)$ with their typical basal lamina $(B L)$ and collagen fibrils $(C F)$. Scale bars: $A, 1 \mu \mathrm{m} ; B, 0.5 \mu \mathrm{m}$.

diating neurite attachment and growth is well established (Bunge and Bunge, 1983; Cornbrooks et al., 1983; Muir et al., 1989; Rende et al., 1990). Schwann cells in the distal nerve stump reexpress both NGF (Heumann et al., 1987; Lemke and Chao, 1988) and NGFr (Taniuchi et al., 1986, 1988). It has been suggested that secreted NGF may bind to low-affinity NGFr on the surface of Schwann cells and to high-affinity NGFr on the tips of extending neurites, attracting neurites toward more distally located Schwann cells, and thus toward the target tissue (Taniuchi et al., 1988). Schwann cells from transected nerves and growing neurites also reexpress cell adhesion molecules (CAMs), including nerve-CAM (N-CAM) and L1 (Nieke and Schachner, 1985; Daniloff et al., 1986; Martini and Schachner, 1988). Both molecules may promote adhesion between Schwann cells and axons (Seilheimer and Schachner, 1988), facilitate the extension of regenerating neurites on the surface of Schwann cells (Daniloff et al., 1986; Bixby et al., 1988; Kleitman et al., 1988; Seilheimer and Schachner, 1988), and participate in myelination processes (Wood et al., 1990). Finally, Schwann cells secrete proteases and proteases inhibitors. Both types of molecules are involved in mediating changes in the anchorage of neuritic membranes to the environment, and thus may promote the advance of growth cones (Monard, 1988).

The physical organization of the Schwann cells in guidance channels may influence the outcome of regeneration. At the time of implantation, channels were filled with an organized cellular cable aligned along their longitudinal axis. The Schwann cells were also oriented along this axis, lying end to end and side by side. It is likely that the presence of this preexisting Schwann cell cable enhanced regenerative processes. It has been demonstrated that the formation of an organized central fibrin cable between the stumps of transected peripheral nerves is critical for successful regeneration (Williams and Varon, 1985; Aebischer et al., 1990). Furthermore, prefilling silicone elastomer channels with an organized fibrin matrix enhances the rate of regeneration of peripheral nerves (Williams, 1987). Thus, by forming an organized cable, the aligned Schwann cells may have served as a preformed scaffold for elongating axons. Therefore, initial regenerative events, including Schwann cell migration, that normally occur in peripheral nerve regeneration were not needed prior to initiation of neurite outgrowth.

The density with which Schwann cells were seeded in tubes influenced the outcome of regeneration. The number of myelinated axons in cables regenerated through channels seeded with the low Schwann cell density (F-40 channels) was close to the myelinated axon counts in empty channels, whereas the myelinated axon counts increased significantly when the seeding density was doubled (F-80 channels) or tripled (F-120 channels). These results suggest that by increasing both the Schwann cell seeding density and the luminal volume of the channels, regenerative potential of artificial guidance tubes may reach the level of nerve autografts. The fact that implanted Schwann cells are directly responsible for the observed effects was not, however, conclusively established in this study. It is also possible that endogenous Schwann cells contributed to the success of nerve regeneration. To assess whether the implanted Schwann cells 
directly interacted with regenerating axons, Schwann cells to be transplanted in guidance channels could be marked while in culture (Price et al., 1987; Langford and Owens, 1990).

The increase in myelinated axon population in the seeded channels could also be partly due to branching of the regenerating axons. Based upon the mean myelinated axon counts, it appeared that axons regenerating in nerve autografts did branch, particularly between $\mathrm{S} 4$ and $\mathrm{S} 6$. In guidance channels, the mean myelinated axon counts did not seem to indicate that branching had occurred. However, to evaluate whether branching happened as axons entered the channels, we calculated the ratio of the number of myclinated axons $2 \mathrm{~mm}$ within the channels to the number of myelinated axons at the entrance of the tubes. Although in all cases fewer axons were counted inside the channels than at the entrance (ratio $<1$ ), there was a statistical increase in ratio values in both F-80 and F-120 channels as compared to control channels. These data can be interpreted to mean either that the presence of Schwann cells stimulated a higher percentage of axons entering the channels to regenerate further and become myelinated or that Schwann cells stimulated some branching in the proximal end of the channels. The possibility that branching occurred more distally within the channels also has not been definitely ruled out. To assess further the axonal branching within the channels, neurons would have to be labeled retrogradely from the distal nerve segment (Mesulam, 1982; Harsh et al., 1991). This would allow the comparison of the number of axons elongating through the channels with the total number of labeled motor and DKG sensory axons.

Heterologous adult Schwann cells seeded in permselective guidance channels induced an immune reaction that impeded regeneration. Myelinated axons did not extend farther than 2 $\mathrm{mm}$ within channels seeded with heterologous Schwann cells, whereas myelinated axons had bridged the nerve gap in channels seeded with syngeneic Schwann cells at a similar density. Morphological analysis showed an immune reaction to outbred Schwann cell implants. Schwann cells in allografts have been shown to express major histocompatibility complex class I and II antigens (Ansselin and Pollard, 1990). These can act as antigen-presenting cells and trigger an immune response that ultimately destroys the transplanted Schwann cells. In experiments using outbred rodent hosts, Kalderon (1988) reported no stimulatory effect of the seeded Schwann cells on peripheral nerve regeneration. The present results suggest that Kalderon's failure to note beneficial effects of transplanted Schwann cells may have been due to an immunological response.

We conclude that Schwann cells isolated from adult rat sciatic nerves and expanded in culture are able to enhance regenerative processes in the PNS and that the density of the Schwann cells in the channels influences the outcome of regeneration. These results suggest ways in which Schwann cells could be used clinically for the repair of peripheral nerves. To avoid immunological rejection, transplantation of autologous Schwann cells would be desirable. Morrissey et al. (1991) have reported a method to isolate Schwann cells from peripheral nerves taken from adult mammals, including humans. We are now attempting to determine if Schwann cells from human sources can be obtained in sufficient numbers with the requisite functional capacities to be useful in the clinical treatment of peripheral nerve injury.

\section{References}

Aebischer P, Guénard V, Winn SR, Valentini RF, Galletti PM (1988) Blind-ended semipermeable guidance channels support peripheral nerve regeneration in the absence of a distal nerve stump. Brain Res 454:179-187.

Aebischer P, Guénard V, Valentini RF (1990) The morphology of regenerating peripheral nerves is modulated by the surface microgeometry of polymeric guidance channels. Brain Res 531:211-218.

Aebischer P, Wahlberg L, Tresco PA, Winn SR (1991) Macroencapsulation of dopamine-secreting cells by coextrusion with an organic solution. Biomaterials 12:50-56.

Anssclin AD, Davey DF (1988) Axonal regeneration through peripheral nerve grafts: the effect of proximo-distal orientation. Microsurgery 9:103-110.

Ansselin AD, Pollard JD (1990) Immunopathological factors in peripheral nerve allograft rejection: quantification of lymphocyte invasion and major histocompatibility complex expression. J Neurol Sci $96: 75-88$.

Bixby JL, Lilien J, Stenwig, AE (1988) Identification of the major proteins that promote neuronal process outgrowth on Schwann cells in vitro. J Cell Biol 107:353-361.

Bunge RP, Bunge MB (1983) Interrelationship between Schwann cell function and extracellular matrix production. Trends Neurosci 6:499505.

Cabasso F (1980) Hollow fiber membranes. In: Encyclopedia of chemical technology, Vol 12 (Kirk-Othner, ed), pp 492-517. New York: Wiley.

Combrooks CJ, Carey DJ, McDonald JA, Timpl R, Bunge RP (1983) In vivo and in vitro observations on laminin production by Schwann cells. Proc Natl Acad Sci USA 80:3850-3854.

Daniloff JK, Levi G, Grumet M, Rieger F, Edelman GM (1986) Altered expression of neuronal cell adhesion molecules induced by nerve injury and repair. J Cell Biol 103:929-945.

Fawcett JW, Keynes RJ (1990) Peripheral merve regeneration. Annu Rev Neurosci 13:43-60.

Guénard V, Valentini RF, Aebischer P (1991) Influence of surface texture of polymeric sheets on peripheral nerve regeneration in a twocompartment guidance system. Biomaterials 12:259-263.

Hall SM (1986a) Regeneration in cellular and acellular autografts in the peripheral nervous system. Neuropathol Appl Neurobiol 12:2746.

Hall SM (1986b) The effect of inhibiting Schwann cell mitosis on the reinnervation of acellular autografts in the peripheral nervous system of the mouse. Neuropathol Appl Neurobiol 12:401-414.

Harsh C, Archibald SJ, Madison RD (1991) Double-labeling of saphenous nerve neuron pools: a model for determining the accuracy of axon regeneration at the single neuron level. J Neurosci Methods 39:123-129.

Heumann R, Korshing S, Bantlow C, Thoenen H (1987) Changes in nerve growth factor synthesis in non-neuronal cell in response to sciatic nerve transection. J Cell Biol 104:1623-1631.

Kalderon N (1988) Differentiating astroglia in nervous tissue histogenesis/regeneration: studies in a model system of regenerating peripheral nerve. J Neurosci Res 21:501-512.

Kleitman N, Simon DK, Schachner M, Bunge RP (1988) Growth of embryonic retinal neurites elicited by contact with Schwann cell surfaces is blocked by antibodies to L1. Exp Neurol 102:298-306.

Kline DG, Hudson AR (1990) Acute injuries of peripheral nerves. In: Neurological surgery, Vol 4 (Youmans JR, ed), pp 2423-2512. Philadelphia: Saunders.

Kromer LF, Cornbrooks CJ (1985) Transplants of Schwann cell cultures promote axonal regeneration in the adult mammalian brain. Proc Natl Acad Sci USA 82:6330-6334.

Kromer LF, Cornbrooks CJ (1987) Identification of trophic factors and transplanted cellular environments that promote CNS axonal regeneration. Ann NY Acad Sci 495:207-224.

Kumar S, Huber J, Peña LA, Perez-Polo JR, Werrbach-Perez K, de Vellis $J$ (1990) Characterization of functional nerve growth factorreceptors in a CNS glial cell line: monoclonal antibody $217 \mathrm{c}$ recognizes the nerve growth factor receptor on C6 glioma cells. J Neurosci Res 27:408-417.

Langford LA, Owens GC (1990) Resolution of the pathway taken by implanted Schwann cells to a spinal cord lesion prior infection with a retrovirus encoding $\beta$-galactosidase. Acta Neuropathol (Berl) 80: 514-520.

LeBeau JM, LaCorbiere M, Powell HC, Ellisman MH, Schubert D (1988) Extracellular fluid conditioned during peripheral nerve re- 
generation stimulates Schwann cell adhesion, migration and proliferation. Brain Res 459:93-104.

Lemke G, Chao M (1988) Axons regulate Schwann cell expression of the major myelin and NGF receptor genes. Development 102:499504.

Lundborg G, Gelberman RH, Longo FM, Powell HC, Varon S (1982) In vivo regeneration of cut nerves encased in silicone tubes. $J$ Neuropathol Exp Neurol 41:412-422.

Madison RD, da Silva C, Dikkes P, Sidman RL, Chiu TH (1987) Peripheral nerve regeneration with entubulation repair: comparison of biodegradable nerve guides versus polyethylene tubes and effect of laminin-containing gel. Exp Neurol 95:378-390.

Martini R, Schachner M (1988) Immunoelectron microscopic localization of neural cell adhesion molecules ( $\mathrm{Ll}, \mathrm{N}-\mathrm{CAM}$ and myelin associated glycoprotein) in regenerating adult mouse sciatic nerve. $J$ Cell Biol 106:1735-1746.

Mesulam MM (1982) Principles of horseradish peroxidase neurohistochemistry and their applications for neural pathways. Axonal transport, Enzyme histochemistry and light microscopy analysis. In: Tracing neural connections with horseradish peroxidase (Mesulam MM, ed), pp 1-149. New York: Wiley.

Monard D (1988) Cell-derived proteases and protease inhibitors as regulators of neurite outgrowth. Trends Neurosci 1 1:541-544.

Morrissey TK, Kleitman N, Bunge RP (1991) Isolation and funclional characterization of Schwann cells derived from adult nerve. J Neurosci 11:2433-2442.

Muir D, Gennrich C, Varon S, Manthrope M (1989) Rat sciatic nerve Schwann cell microcultures. Responses to mitogens and production of trophic and neurite-promoting factors. Neurochem Res 14:10031012.

Nieke J, Schachner M (1985) Expression of the neural cell adhesion molecules N-CAM and LI and their common epitope I.2-HNK-1 during development and after transection of adult mouse sciatic nerve. Differentiation 30:141-151.

Pollard JD, McLcod JG, Gye RS (1973) Regeneration through peripheral nerve allografts: an electrophysiological and histological study following the use of immunosuppressive therapy. Arch Neurol 28: 31-37.

Porter S, Clark HB, Glaser L, Bunge RP (1986) Schwann cells stimulated to proliferate in the absence of neurons retain full functional capability. J Neurosci 6:3070-3078.
Price J, Turner D, Cepko C (1987) Lineage analysis in the vertebrate nervous system by retrovirus-mediated gene transfer. Proc Natl Acad Sci USA 84:156-160.

Rende M, Hagg T, Magal E, Varon S (1990) Ciliary neurotrophic factor immunoreactivity in the rat sciatic nerve. Soc Neurosci Abstr $16: 807$.

Seilheimer B, Schachner M (1988) Studies of adhesion molecules mediating interactions between cells of peripheral nervous system indicate a major role for $\mathrm{Ll}$ in mediating sensory neuron growth on Schwann cells in culture. J Cell Biol 107:341-351.

Shine HD, Harcourt PG, Sidman RL (1985) Cultured peripheral nervous system cells support peripheral nerve regeneration through tubes in the absence of distal nerve stump. J Neurosci Res 14:393-401.

Smith GV, Stevenson JA (1988) Peripheral nerve grafts lacking viable Schwann cells fail to support central nervous system axonal regeneration. Exp Brain Res 69:299-306.

Taniuchi M, Clark HB, Johnson EM (1986) Induction of nerve growth factor receptors in Schwann cells after axotomy. Proc Natl Acad Sci USA 83:4094-4098.

Taniuchi M, Clark MB, Schweitzer JB, Johnson EM (1988) Expression of nerve growth factor receptors by Schwann cells of axotomized peripheral nerves: ultrastructural localization, suppression by axonal contact, and binding properties. J Neurosci 8:664-681.

Valentini RF, Aebischer P, Winn SR, Galletti PM (1987) Collagen and laminin containing gels impeded peripheral nerve regeneration through semi-permeable nerve guidance channels. Exp Neurol 98: 325-338.

Williams LR (1987) Exogenous fibrin precursors stimulate the temporal progress of nerve regeneration within a silicone chamber. Neurochem Res 12:851-860.

Williams LR, Varon S (1985) Modification of fibrin matrix formation in situ enhances nerve regeneration within a silicone chamber. J Comp Neurol 231:209-220.

Williams LR, Longo FM, Powell FM, Lundborg G, Varon S (1983) Spatial-temporal progress of peripheral nerve regeneration within a silicone chamber: parameters for a bioassay. J Comp Neurol 218: $460-470$.

Wood PM, Schachner M, Bunge RP (1990) Inhibition of Schwann cell myelination in vitro by antibody to the $\mathrm{L} 1$ adhesion molecule. $\mathrm{J}$ Neurosci 10:3635-3645. 